\title{
KEMAMPUAN PEMAHAMAN KONSEP MATEMATIS DITINJAU DARI MOTIVASI BELAJAR SISWA SMP NEGERI 31 PALEMBANG
}

\author{
Yosi Ismawati ${ }^{*}$, Yusuf Hartono ${ }^{* *}$, Destiniar ${ }^{* * * *}$ \\ Universitas PGRI Palembang ${ }^{*, * * *}$, Universitas Sriwijaya Palembang ${ }^{* *}$ \\ yosiismawati75100@gmail.com*,y_hartono@yahoo.com ${ }^{* *}$, \\ destiniarpgri@yahoo.co.id ${ }^{* * *}$
}

\begin{abstract}
Abstrak: Penelitian ini bertujuan untuk mengetahui Pemahaman Konsep Matematis ditinjau dari motivasi belajar Siswa SMP Negeri 31 Palembang. Penelitian ini menggunakan rancangan True Eksperimental dengan Post Test Only Group Design. Sampel dalam penelitian ini berjumlah 61 orang siswa. Data dikumpulkan dengan tes dan angket, dan dianalisis menggunakan uji-t. Hasil penelitian menunjukkan bahwa pemahaman konsep matematis siswa yang memiliki tingkat motivasi belajar tinggi lebih baik dari pada siswa yang memiliki tingkat motivasi sedang atau rendah.
\end{abstract}

Kata Kunci: pemahaman konsep; motivasi belajar.

\section{PENDAHULUAN}

Dalam

pembelajaran matematika, pemahaman konsep itu merupakan landasan yang sangat penting untuk berpikir dalam menyelesaikan masalah yang ada dalam matematika. Kesumawati (2008) menyatakan bahwa "Siswa dikatakan memahami konsep jika siswa mampu mendefinisikan konsep, mengidentifikasi dan memberi contoh atau bukan contoh dari konsep, mengembangkan kemampuan koneksi matematik antar berbagai ide, memahami bagaimana ide-ide matematik saling terkait satu sama lain sehingga terbangun pemahaman menyeluruh, dan menggunakan matematik dalam konteks di luar matematika.

Dian menyatakan salah satu penyebab kegagalan dalam pembelajaran matematika adalah siswa tidak paham konsep-konsep matematika atau siswa salah dalam memahami konsep matematika.

Kenyataannya yang terjadi saat ini, kemampuan pemahaman konsep matematika siswa masih tergolong rendah. Hal ini seperti disampaikan oleh Sari (2017) bahwa rendahnya kemampuan pemahaman konsep siswa, diakibatkan oleh siswa kurang aktif dan kurang berinisiatif untuk mempelajari sendiri pelajaran yang akan dipelajari. Sedangkan Riawan (2014) mengatakan bahwa rendahnya pemahaman konsep matematis siswa SMP dipengaruhi oleh kurangnya antusias siswa untuk belajar, siswa hanya menerima informasi yang disampaikan oleh guru, diam dan tidak mau mengemukakan pertayaan maupun pendapat. Hal tersebut di ketahui bahwa rendahnya kemampuan pemahaman konsep matematika karna siswa kurang antusias dan kurang berinisiatif dalam menerima pembelajaran dan cendrung 
tidak mau berbagi pengetahuan dengan temannya sehingga siswa kesulitan untuk mengerjakan soal yang diberikan oleh guru.

Motivasi adalah dorongan yang terdapat dalam diri seseorang untuk berus aha mengadakan perubahan tingkah laku yang lebih baik dalam memenuhi kebutuhannya. (Uno, 2016). Sejalan dengan itu Motivasi juga merupakan suatu usaha yang disadari untuk menggerakkan, mengarahkan dan menjaga tingkah laku seseorang agar ia terdorong untuk bertindak melakukan sesuatu sehingga mencapai hasil tujuan tertentu (Hamdu, 2011). Motivasi menurut Suprihatin diartikan sebagai kekuatan seseorang yang dapat menimbulkan tingkat kemauan dalam melaksanakan suatu kegiatan. Dalam kegiatan belajar, motivasi dapat dikatakan sebagai keseluruhan daya penggerak di dalam diri siswa yang menimbulkan kegiatan belajar, yang menjamin kelangsungan dan memberikan arah pada kegitan belajar, sehingga tujuan yang dikehendaki oleh subjek itu bisa tercapai.

Adapun rumusan masalah dari penelitian ini adalah "Apakah ada perbedaan kemampuan Pemahaman Konsep Matematis ditinjau dari motivasi belajar tinggi dan sedang Siswa SMP Negeri 31 Palembang?". Tujuan yang ingin dicapai oleh peneliti adalah adalah untuk mengetahui ada atau tidak adanya perbedaan kemampuan Pemahaman Konsep Matematis ditinjau dari motivasi belajar tinggi dan sedang Siswa SMP Negeri 31 Palembang.

\section{LANDASAN TEORETIS}

Pemahaman konsep merupakan kompetensi yang ditunjukkan siswa dalam memahami konsep dan dalam melakukan prosedur (algoritma) secara luwes, akurat, efisien, dan tepat (Mona dkk, 2012) Sejalan dengan itu Pemahaman konsep juga merupakan kemampuan siswa yang berupa penguasaan sejumlah materi pelajaran, di mana siswa tidak sekedar mengetahui atau mengingat sejumlah konsep yang di pelajari, tetapi mampu mengungkapkan kembali dalam bentuk lain yang mudah di mengerti, memberikan interprestasi data dan mampu mengaplikasihkan konsep sesuai dengan struktur kognitif yang dimilikinya (Rohaenur, 2014).

Berdasarkan hal tersebut kemampuan pemahaman konsep matematika merupakan salah satu kecakapan atau kemahiran matematika yang diharapkan dapat tercapai dalam belajar matematika yaitu dengan menunjukkan pemahaman konsep matematika yang dapat menginterpresentasikan, mengklasifikasikan, menjelaskan, merumuskan, menghitung, suatu materi secara luwes, akurat, efisien, dan tepat.

Indikator bahwa siswa dapat dikatakan paham terhadap konsep matematika, dapat dilihat dari kemampuan siswa dalam beberapa hal sebagai berikut: (Lestari \& Ridwan, 2015)

1. Menyatakan ulang sebuah konsep yang telah dipelajari. 
2. Mengklasifikasikan objek menurut sifat-sifat tertentu sesuai dengan konsepnya

3. Menerapkan konsep secara algoritma.

4. Memberi contoh dan bukan contoh dari suatu konsep

5. Menyajikan konsep dalam berbagai bentuk representasi matematis.

6. Mengaitkan berbagai konsep matematika secara internal atau eksternal.

Wardani (2008) menyatakan indikator bahwa siswa dapat dikatakan paham terhadap konsep matematika, dapat dilihat dari kemampuan siswa dalam beberapa hal sebagai berikut :

1. Menyatakan ulang sebuah konsep.

2. Mengklasifikasikan objek menurut sifat-sifat tertentu sesuai dengan konsepnya.

3. Memberi contoh dan bukan contoh dari suatu konsep.

4. Menyajikan konsep dalam berbagai bentuk representasi matematis.

5. Mengembangkan syarat perlu atau syarat cukup dari suatu konsep.

6. Menggunakan dan memanfaatkan serta memilih prosedur atau operasi tertentu.

7. Mengaplikasikan konsep atau algoritma pada pemecahan masalah.

Motivasi adalah dorongan yang terdapat dalam diri seseorang untuk berusaha mengadakan perubahan tingkah laku yang lebih baik dalam memenuhi kebutuhannya (Uno,2016). Sejalan dengan itu Motivasi juga merupakan suatu usaha yang disadari untuk menggerakkan, mengarahkan dan menjaga tingkah laku seseorang agar ia terdorong untuk bertindak melakukan sesuatu sehingga mencapai hasil tujuan tertentu (Hamdu \& Agustina, 2011). Motivasi menurut Suprihatin (2015) diartikan sebagai kekuatan seseorang yang dapat menimbulkan tingkat kemauan dalam melaksanakan suatu kegiatan. Dalam kegiatan belajar, motivasi dapat dikatakan sebagai keseluruhan daya penggerak di dalam diri siswa yang menimbulkan kegiatan belajar, yang menjamin kelangsungan dan memberikan arah pada kegitan belajar, sehingga tujuan yang dikehendaki oleh subjek itu bisa tercapai. Menurut Uno (2016), indikator motivasi belajar diklasifikasikan sebagai berikut :

1. Adanya hasrat dan keinginan berhasil

2. Adanya dorongan dan kebutuhan dalam belajar.

3. Adanya harapan dan cita-cita masa depan.

4. Adanya penghargaan dalam belajar.

5. Adanya kegiatan yang menarik dalam belajar.

6. Adanya lingkungan belajar yang kondusif.

Selanjutnya Indikator Motivasi Belajar menurut Sardiman (2011) adalah (1) tekun menghadapi tugas; (2) ulet menghadapi kesulitan; (3) menunjukkan minat terhadap bermacam-macam masalah; (4) lebih senang bekerja mandiri; (5) cepat bosan pada tugas-tugas yang rutin; (6) dapat mempertahankan pendapatnya; (7) tidak mudah melepaskan hal yang 
mudah diyakini; (8) senang mencari dan memecahkan masalah soal-soal.

\section{METODOLOGI PENELITIAN}

Metode yang digunakan dalam penelitian ini adalah metode penelitian eksperimen. Rancangan perlakuan Postest-Only Control Design. Penelitian ini dilaksanakan pada semester ganjil tahun ajaran 2018/2019, dengan lokasi penelitan adalah SMP Negeri 31 Palembang, subjek penelitian adalah siswa kelas VIII. Teknik yang digunakan dalam pengambilan sample pada penelitian ini adalah Teknik Cluster Sampling. Di mana yang akan diambil dua kelas dari seluruh kelas VIII di SMP Negeri 31 Palembang, di mana kelas VIII.2 sebagai kelas Eksperimen dan kelas VIII.3 sebagai kelas Kontrol. Data dikumpulkan dengan tes dan angket, dan dianalisis menggunakan uji-t. Soal tes yang diberikan kepada siswa berjumlah 5 soal, di mana soal tersebut sebelum diberikan kepada siswa sudah terlebih dahulu di validasi oleh Dosen Matematika dan Guru Matematika.

\section{HASIL DAN PEMBAHASAN}

Pada bagian ini akan dideskripsikan hasil post-test siswa pada masing-masing kelas, yaitu kelas eksperimen dengan startegi Active Knowledge Sharing dan kontrol dengan model konvensional.

Data diperoleh dari hasil tes akhir yang berupa jawaban siswa yang kemudian dianalisis dengan soal tes yang mengacu pada kemampuan pemahaman konsep matematika. Hasil tes akhir siswa kemampuan pemahaman konsep matematika. Dari pengujian nilai rata-rata kemampuan pemahaman konsep matematis siswa pada kelas eksperimen yaitu 72,20 dan kelas kontrol yaitu 63,96.

\section{Tabel 1}

Rata-rata Berdasarkan Motivasi Belajar (Tinggi,Sedang) Siswa terhadap Kemampuan Pemahaman Konsep Matematika Siswa

\begin{tabular}{|c|c|c|c|c|}
\hline \multirow{3}{*}{$\begin{array}{c}\text { Motivasi } \\
\text { Belajar }(\mathbf{B})\end{array}$} & \multirow{3}{*}{ Statistik } & \multicolumn{2}{|c|}{$\begin{array}{c}\text { Kemampuan Pemahaman Konsep } \\
\text { Matematis }\end{array}$} & \multirow{3}{*}{ Jumlah } \\
\hline & & Str: & Pembelajaran (A) & \\
\hline & & $A C S$ (a1) & KONVENSIONAL (a2) & \\
\hline \multirow{2}{*}{ Tinggi (b1) } & $\mathrm{N}$ & 11 & 7 & 18 \\
\hline & $\bar{x}$ & 79,82 & 75,43 & 77,63 \\
\hline \multirow{2}{*}{$\begin{array}{c}\text { Sedang } \\
(\text { b2) }\end{array}$} & $\mathrm{N}$ & 19 & 24 & 43 \\
\hline & $\bar{x}$ & 67,79 & 59,46 & 63,63 \\
\hline \multirow{2}{*}{ Jumlah } & $\mathrm{N}$ & 30 & 31 & 61 \\
\hline & Rata-rata & 73,80 & 67,44 & 70,63 \\
\hline
\end{tabular}

Dari analisis data tes seperti pada tabel di atas, disimpulkan bahwa kelompok siswa dengan motivasi belajar tinggi yang mendapatkan perlakuan strategi ACS dengan jumlah 11 orang dan rata-rata 79,82 lebih tinggi dibandingkan dengan kelompok siswa dengan motivasi belajar tinggi yang mendapatkan perlakuan konvensional dengan jumlah 7 orang dan rata-rata 75,43 . Kemudian bahwa kelompok siswa 
dengan motivasi belajar sedang yang mendapatkan perlakuan strategi ACS dengan jumlah 19 orang dan rata-rata 67,79 lebih tinggi dibandingkan dengan kelompok siswa dengan motivasi belajar sedang yang mendapatkan perlakuan konvensional dengan jumlah 24 orang dan rata-rata 59,46

Adapun uji hasil Independent Sampel T-Test, berdasarkan perhitungan uji-t tes kemampuan pemahaman konsep matematika di peroleh sig. (2-tailed) adalag 0,000 < 0,025 berdasarkan kriteria pengujian maka $\mathrm{H}_{\mathrm{o}} \quad$ diterima sehingga disimpulkan bahwa Pemahaman Konsep Matematika Siswa yang memiliki tingkat motivasi belajar tinggi lebih baik dari pada siswa yang memiliki tingkat motivasi belajar sedang.

Menurut Pranata (2016) pemahaman konsep adalah perbuatan, cara memahami ide-ide materi pembelajaran. di mana siswa tidak sekedar mengenal dan mengetahui, tetapi mampu mengungkapkan kembali konsep dalam bentuk yang lebih mudah dimengerti serta mampu mengaplikasikannya.

Hal ini sejalan dengan pendapat Kesumawati (2008) yang menyatakan bahwa dalam proses pembelajaran matematika, pemahaman konsep merupakan bagian yang sangat penting. Pemahaman konsep matematika merupakan landasan penting untuk berpikir dalam menyelesaikan permasalahan matematika maupun permasalahan sehari-hari.
Siswa dapat dikatakan memiliki pemahaman konsep apabila siswa tersebut dapat menyelesaikan soal yang dibuat berdasarkan indikator pemahaman konsep. Hal ini terungkap dari hasil penelitian Kesumawati (2008) yang menyatakan siswa dikatakan memahami konsep jika mampu mendefinisikan konsep, mengidentifikasi dan memberi contoh atau bukan contoh dari konsep, mengembangkan kemampuan koneksi matematik antar berbagai ide, memahami bagaimana ide-ide matematik saling terkait satu sama lain sehingga terbangun pemahaman menyeluruh, dan menggunakan matematik dalam konteks di luar matematika. Menurut Mutuharo (2015) ada hubungan yang positif antara motivasi belajar terhadap pemahaman konsep siswa kelas VIII SMP Negeri 21 Surabaya dan termasuk dalam kategori hubungan kuat. Semakin tinggi motivasi belajar maka pemahaman konsep siswa akan menjadi semakin baik pula.

Begitu juga menurut Rini (2016) ada perbedaan yang signifikan antara pemahaman konsep matematika siswa kelas X Madrasah Aliyah Negeri 1 Palu yang mempunyai motivasi belajar tinggi dengan pemahaman konsep matematika siswa yang mempunyai motivasi belajar rendah. Hal ini sejalan dengan penelitian yang dilakukan oleh peneliti bahwa pemahaman konsep matematis siswa yang memiliki tingkat motivasi belajar tinggi lebih baik dari pada siswa yng memiliki tingkat motivasi sedang. 


\section{SIMPULAN DAN SARAN}

Berdasarkan hasil analisis data dan pengujian hipotesis bahwa ada: perbedaan kemampuan pemahaman konsep matematis ditinjau dari motivasi belajar tinggi dan sedang siswa SMP Negeri 31 Palembang.

Berdasarkan penelitian yang telah dilakukan oleh peneliti maka saran yang dapat direkomendasikan oleh peneliti adalah sebagai berikut :

1. Dapat dijadikan referensi dalam pelaksanaan pembelajaran metamatika untuk meningkatkan kemampuan pemahaman konsep matematis siswa,

2. Dapat digunakan dalam mengoptimalkan kemampuan Pemahaman Konsep matematis siswa.

\section{DAFTAR PUSTAKA}

A. M. Sardiman. (2011) Interaksi dan Motivasi Belajar Jakarta: Raja Grafindo Persada.

Dewi, Asri Nafi'a. (2012). Pengaruh Penggunaan Model Active Knowladge Sharing Terhadap Hasil Belajar Ditinjau dari Minat Belajar Siswa SMA N 2 Karanganyar. Jurnal

Pendidikan Biologi. h. 4

Fatqurhohman. Pemahaman Konsep Matematika Siswa Dalam Menyelesaiakan Masalah Bangu n Data.

Tersedia

Retrieved From file:///C:/Users /win7/Downloads/847-1567-1SM.pdf.

Hamalik, Oemar. (2012). Pendekatan Baru Strategi Belajar Mengajar Berdasarkan CBSA. Bandung: Penerbit Sinar Baru Algensindo Bandung.
Hamdu, Ghullam \& Lisa Agustina. Pengaruh Motivasi belajar Siswa Terhadap Prestasi Belajar IPA Di Sekolah Dasar. Vol.12 No 1

Kamal, Muhiddinur. (2014).Strateg.i Active Knowladge Sharing Dalam Meningkatkan Motivasi Belajar Siswa SD/MI. Jurnal Tarbiah al-Awlad. Vol IV No 1 h. 370

Kamarulla. (2017). Pendidikan Matematika Di Sekolah Kita. Tersedia https://jurnal.arraniry.a c.id/index.php/alkhawarizmi/art icle/view/1729/1272

Kesumawati, Nila. (2008). Pemahaman Konsep Matematik dalamPembelajaran Matematika Tersedia.http://eprints.uny.ac.id /6928/1/P18\%20Pendidikan\%2 8Nila\%20K\%29.pdf

Lestari, Karunia Eka dan Mokhammad Ridwan Yudhanegara. (2015). Penelitian Pendidikan Matematika, Bandung: Refika Aditama.

M., Padma Mike Putri dkk. (2012). Pemahaman Konsep Matematika Pada Materi Turunan Melalui Pembelajaran Teknik Probing. Tersedia file:///C:/Users/8 Dow nloads/1173-2529-1-SM.pdf.

Motoharo, Siti Zuli (2015) Hubungan Motivasi Belajar Terhadap Pemahaman Konsep Pada Siswa Kelas VIII Smp Negeri 21 Surabaya. Tersedia http://jurnalmahasiswa.unesa.ac .id/index.php/pensa/article/view $/ 11505$

Novitasari, Dian. (2016). Pengaruh Pengunaan Multimedia Interktif Terhadap 
Pemahaman Konsep Matematis Siswa. Jurnal Pendidikan Matematika \& Matematika Vol 2 No 2

Pranata, Ella. (2016). Implementasi Model Pembelajaran Group Investigation (GI) Berbantuan Alat Peraga Untuk Meningkatkan Kemampuan Pemahaman

Konsep Matematika. Tersedia https://media.neliti.com/media/ publications/181385-idimplementasi-modelpembelajaran-group-in.pdf.

Rini,Eva Setya.(2016) Pemahaman Konsep Dan Motivasi Belajar Matematika Siswa Kelas X Madrasah Aliyah Negeri 1 Palu Melalui Model Pembelajaran Berbasis Masalah Dan Model Pembelajaran Inkuiri.e-jurnal Mitra Sains, Volume 4 Nomor 2, April 2016.

Rohaenur. (2014). Penerapan Pendekatan Matematika Realistik Untuk Meningkatkan Pemahaman Konsep Dasar Pecahan pada Siswa Kelas IVB SDLB SUKOHARJO, MARGOREJO, PATI.. jurnal pendidikan Universitas Muhammadiyah Surakarta.

Sari, Ida Ratna, dkk. (2017). Pengaruh Penerapan Strategi Pembelajaran Aktif Tipe The Learning cell Terhadap Pemehaman Konsep Matematis Siswa kelas VII SMPN 4 Batang Anai Kabupaten Padang Pariaman. Vol 3 No.1, April
Silberman,Melvin L. (2017).Active Learning 101 Cara Belajar Siswa Aktif. Bandung:Nuansa Cendekia

Sudjana, H. Nana. (2010). Cara belajar siswa aktif dalam proses belajar mengajar. Bandung:: Sinar Baru Algensindo.

Sumargiyani. (2015). Efektivitas Penggunaan Model Pembelajaran Number Head Together Terhadap hasil Belajar Matematika Siswa SMP. Tersedia http://eprints.uad.ac.id/2829/1/s umargiyaniJurnal\%20admathedu.pdf

Suprihatin, Siti. Upaya Guru Meningkatkan Motivasi Belajar Siswa. Dalam jurnal Vol 3. No 1

Uno, Hamzah. B. (2016). Teori Motivasi dan Pengukurannya. Jakarta : PT.Bumi Aksara.

Wardhani, Sri. (2008). Analisis SI dan SKL pada mata pelajaran Matematika SMP/MTS untuk Optimalisasi Tujuan Mata Pelajaran matematika. Yogjakarta: pusat pengembangan dan pemberdayaan pendidikan dan tenaga kependidikan matematika.

Zevika, Mona dkk. (2012). Meningkatkan Kemampuan Pemahaman Konsep Siswa Kelas VIII SMPN 2 Padang Panjang Mellaui Pembelajran Kooperatif tipe TPS di Sertai Peta Pikiran. Vol 1 No.1. 